\begin{tabular}{|c|c|c|c|c|}
\hline $\begin{array}{c}\text { JURNAL } \\
\text { KOLABORASI RESOLUSI KONFLIK }\end{array}$ & VOLUME 1 & NOMOR 1 & HALAMAN 1-70 & $\begin{array}{c}\text { ISSN 2655-8823 }(p) \\
\text { ISSN - }(e)\end{array}$ \\
\hline
\end{tabular}

\title{
PENERAPAN MANAJEMEN KONFLIK DALAM PENYELESAIAN SENGKETA LAHAN ANTARA PETANI DENGAN KORPORASI PROPERTI DI KABUPATEN KARAWANG
}

\author{
Fadilla Rama Widapratama \\ Mahasiswa Program Studi Kesejahteraan Sosial FISIP UNPAD \\ E-mail: fadillaramawidapratama35@gmail.com \\ Rudi Saprudin Darwis \\ Dosen Program Studi Kesejahteraan Sosial FISIP UNPAD \\ Email: rsdarwis@gmail.com
}

\begin{abstract}
ABSTRAK
Konflik merupakan suatu peristiwa atau fenomena sosial yang menjadi bagian dari dinamika kehidupan manusia. Sering kali konflik memberikan dampak negatif terhadap pihak yang berkonflik seperti timbulnya permusuhan yang berkelanjutan (bubuyutan), kerugian materil bahkan hingga jatuhnya korban jiwa. Meskipun demikian, konflik pun mampu menjadi suatu aspek pendukung dalam keberlangsungan hidup yang lebih baik. Hal tersebut dapat terjadi bila konflik dapat dikelola dengan baik dan mampu memanfaatkan kondisi atau latar belakang konflik yang dapat mempersatukan antar pihak yang berkonflik dengan prinsip win-win solution. Dalam artikel ini, penulis berupaya untuk membuat suatu upaya penyelesaian masalah dalam bentuk plan of treatment terhadap konflik yang terjadi di Kab. Karawang, Jawa Barat, yang melibatkan pihak petani padi yang terkena gusur oleh korporasi properti PT. Agung Podomoro Land. Dalam kasus ini, para petani Kab. Karawang yang bertempat di Kec. Teluk Jambe Barat merasa dirugikan atas inkonsistensi pihak pengembang dalam pemberian ganti rugi yang tidak sesuai dengan janji atas akuisisi lahan milik para petani. Hingga saat ini, kasus ini belum menemukan titik terang dalam penyelesaian konflik antara kedua belah pihak walaupun beberapa aliansi agraria Indonesia telah mengajukan banding atas ketidakadilan yang terjadi atas hak kepemilikan lahan, padahal lahan tersebut sudah digunakan pengembang dengan dibangunkannya apartemen dan pusat perbelanjaan modern. Atas dasar itu, diperlukan intervensi berbasis manajemen konflik serta resolusi konflik guna memberikan keadilan dan pemenuhan hak para petani Kec. Teluk Jambe Barat, Kab. Karawang. Bentuk intervensi tersebut pun harus menghasilkan dampak positif bagi kedua belah pihak yang berkonflik guna menciptakan kehidupan sosial yang harmoni.
\end{abstract}

Kata kunci: Intervensi, Konflik, Manajemen Konflik, Petani Padi.

\section{ABSTRACT}

Conflict is an event or social phenomenon that is part of the dynamics of human life. Often conflicts have a negative impact on parties in conflict such as the emergence of ongoing hostilities (bubuyutan), material losses even to the loss of life. Even so, conflict can also be a supporting aspect of better survival. This can happen if the conflict can be managed properly and is able to take advantage of the conditions or background of the conflict that can unite the conflicting parties with the principle of a win-win solution. In this article, the author seeks to make an effort to solve the problem in the form of a plan of treatment of conflicts that occur in Kab. Karawang, West Java, which involves the farmers who are affected by the property corporation PT. Agung Podomoro Land. In this case, the farmers of Kab. Karawang which is located in the district West Telukjambe feels disadvantaged by the inconsistency of the developer in providing compensation that is not in line with the promise of the acquisition of land owned by the farmers. Until now, this case has not found a bright spot in resolving the conflict between the two parties even though some Indonesian agrarian alliances have appealed against injustice that happened to land ownership rights, even though the land has been used by developers with the construction of apartments and modern shopping centers. Based on that, conflict management and conflict resolution based interventions are needed to provide justice and fulfillment of the rights of farmers in the district West Telukjambe, Kab. Karawang. This form of intervention must have a positive impact on both parties in conflict to create a harmonious social life.

Keywords: Conflict, Farmers, Intervention, Management Conflict. 


\begin{tabular}{|c|c|c|c|c|}
\hline JURNAL & VOLUME 1 & NOMOR 1 & HALAMAN 1-70 & $\begin{array}{c}\text { ISSN 2655-8823 }(p) \\
\text { ISSN - }(e)\end{array}$ \\
\hline
\end{tabular}

\section{PENDAHULUAN}

Konflik merupakan suatu peristiwa atau fenomena sosial yang senantiasa menjadi bagian dari dinamika kehidupan manusia. Konflik dipandang sebagai gejala sosial yang terjadi pada kehidupan sosial dalam berbagai tingkatan. Seperti apapun tingkat konflik itu terdapat dalam masyarakat, suatu konflik memerlukan penanganan agar tidak menimbulkan kerusakan dalam kehidupan masyarakat.

Marx (1867) memiliki pandangan bahwa konflik sosial merupakan perihal pertentangan kelas. Sama halnya yang terjadi dalam kasus sengketa lahan pertanian yang terjadi pada Kabupaten Karawang, Kecamatan Teluk Jambe Barat yang dipandang masyarakat sebagai bentuk perampasan. Sesuai dengan teori konflik yang disampaikan oleh Marx, bahwa konflik dapat terjadi akibat adanya kepentingan ekonomi antara orang-orang yang berbeda kelas. Konflik antara petani Kab. Karawang dengan PT. Agung Podomoro Land (APL) ini membuktikan fenomena adanya pertentangan diantara pihak yang memiliki kepentingan perekonomian. Berbagai media massa telah memberitakan isue tersebut sejak kasus tersebut muncul hingga tahun 2018 yang ternyata masih menyisakan persoalan.

Meskipun Pengadilan Negeri Karawang telah memenangkan PT. APL dalam sengketa lahan dengan petani bahkan sampai dengan tingkat kasasi, para petani masih belum dapat menerima keputusan tersebut. Para petani tidak dapat menerima keputusan yang telah ditetapkan sejak tahun 2007 tersebut karena pihak PT. APL belum memberikan hak para petani secara penuh dalam proses pengalihan hak atas lahan yang disengketakan dan menganggap bahwa keputusan yang memenangkan pihak PT. APL sebagai keputusan yang sudah diatur.

Ketidakpuasan tersebut terus berlanjut sehingga pada tahun 2018 para petani dari tiga desa di Kecamatan Telukjambe Barat, Kab. Karawang, bersama ribuan kelompok masyarakat dari lembaga swadaya masyarakat menuntut pengembalian lahannya dari PT. APL. Yang memperjuangkan hak para petani tidak hanya para petani yang bersengketa saja, namun juga pihak-pihak lain simpati dan berkepentingan dengan isue sengketa lahan tersebut, seperti lembaga-lembaga swadaya masyarakat.

Ketidakadilan yang terjadi dalam kasus sengketa lahan pertanian di Kab. Karawang ini menarik simpati dan keterlibatan dari berbagai aliansi agraria di Indonesia hingga kepada aliansi pelajar Indonesia. Gerakan berupa dukungan yang dilakukan tak lain untuk menuntuk hak yang seharusnya dimiliki oleh pihak petani Kab. Karawang atas kepemilikan lahan yang terampas. Latar belakang kesamaan nasib menjadi awal tumbuhnya solidaritas terhadap pejuang lain yang mempertahankan hak dan memperjuangkan keadilan sosial atas sumber kekayaan alam.

Belajar dari pengalaman sejarah Indonesia, rasa senasib-sepenanggunan sebagai sesama kaum tertindas, dapat menumbuhkan satu pertalian gerakan perlawanan terhadap penjajahan. Kini solidaritas mulai tumbuh terhadap sesama pejuang agraria dan para petani yang tertindas di negerinya sendiri. Para Petani Karawang mendapatkan simpati dari khalayak luas karena upaya keras mereka dalam mempertahankan tanah mereka dari pengambilalihan lahan secara paksa.

Resolusi konflik melalui manajemen konflik nampaknya menjadi upaya yang penting dalam penyelesaian konflik sosial. Kerugian materi hingga jatuhnya korban jiwa menjadi resiko yang harus dialami masyarakat ketika mengalami konflik. Manajemen konflik menjadi harapan masyarakat agar proses penyelesaian konflik dapat menciptakan masyarakatvyang harmonis. Untuk itu perlu kesediaan semua pihak yang berkonflik untuk berkontribusi dalam penyelesaian konflik. Jika konflik disikapi dengan berorientasikan egosentris dan kepentingan sepihak, maka konflik akan selalu menjadi 


\begin{tabular}{|c|c|c|c|c|}
\hline $\begin{array}{c}\text { JURNAL } \\
\text { KOLABORASI RESOLUSI KONFLIK }\end{array}$ & VOLUME 1 & NOMOR 1 & HALAMAN 1-70 & $\begin{array}{c}\text { ISSN 2655-8823 }(p) \\
\text { ISSN - }(e)\end{array}$ \\
\hline
\end{tabular}

konflik tidak terselesaiakn dalam kehidupan sosial.

\section{KAJIAN PUSTAKA Pengertian Konflik}

Konflik adalah hubungan antara dua pihak atau lebih (individu atau kelompok) yang memiliki atau yang merasa memiliki sasaran-sasaran yang tidak sejalan. Konflik berbeda dengan kekerasan. Kekerasan meliputi tindakan, perkataan, sikap dan berbagai struktur atau sistem yang menyebabkan kerusakan secara fisik, mental sosial dan lingkungan. Konflik akan terjadi ketika tujuan masyarakat tidak sejalan. Konflik timbul karena ketidakseimbangan antara hubunganhubungan itu, seperti kesenjangan status sosial, kurang meratanya kemakmuran serta kekuasaan yang tidak seimbang yang kemudian menimbulkan masalah-masalah seperti diskriminasi, penindasan, pengangguran, kejahatan dan lainnya.

Adapun jenis-jenis konflik yang sering terjadi menurut Fisher (2001), yaitu:

1. Konflik laten, sifatnya tersembunyi dan perlu diangkat ke permukaan sehingga dapat ditangani secara efektif

2. Konflik manifest, sifatnya terbuka yang berakar dalam dan sangat nyata serta perlu berbagai tindakan untuk mengatasi akar penyebab dan berbagai efeknya.

3. Konflik di permukaan, terjadi karena kesalahpahaman dan dapat diatasi dengan meningkatkan komunikasi.

Selanjutnya Fisher (2001:7-8) membuat kategorisasi penyebab konflik berdasarkan teori yang mendasarinya sebagai berikut :

a. Teori Hubungan Masyarakat

Konflik disebabkan oleh polarisasi yang terus terjadi. Adanya ketidakpercayaan dan permusuhan diantara kelompok yang berbeda dalam suatu masyarakat.

b. Teori Negosiasi Prinsip
Konflik disebabkan oleh posisiposisi yang tidak selaras dan perbedaan pandangan tentang konflik oleh pihak-pihak yang mengalami konflik.

c. Teori Kebutuhan Manusia

Konflik yang berakar dalam disebabkan oleh kebutuhan dasar manusia baik fisik, mental dan sosial yang tidak terpenuhi. Inti pembicaraannya adalah tentang keamanan, identitas, pengakuan, partisipasi dan otonomi.

d. Teori Identitas

Konflik disebabkan karena identitas yang terancam, sering berakar pada hilangnya sesuatu atau penderitaan di masa lalu yang tidak diselesaikan.

e. Teori Kesalahpahaman Antar Budaya

Konflik disebabkan karena ketidakcocokan dalam cara-cara berkomunikasi antar budaya yang berbeda.

f. Teori Transformasi Konflik

Konflik disebabkan oleh masalah-masalah ketidakadilan, ketidaksetaraan yang muncul sebagai masalah sosial, budaya dan ekonomi.

Dalam mengelola konflik, harus dipahami bahwa konflik dalam masyarakat terkait dengan kondisi struktur sosialnya. Aspek-aspek yang mempengaruhi struktur sosial sehingga mempengaruhi kondisi konflik yang timbul dalam masyarakat, yaitu:

1. Partisipasi

Dalam suatu masyarakat yang memiliki perdamaian positif diartikan masyarakat cukup diberdayakan sehingga mereka berpartisipasi secara aktif dalam pengambilan keputusan. Konflik harus dikelola secara kreatif dan konstruktif. Seluruh masyarakat memiliki hak bersuara, baik wanita, 


\begin{tabular}{|c|c|c|c|c|}
\hline $\begin{array}{c}\text { JURNAL } \\
\text { KOLABORASI RESOLUSI KONFLIK }\end{array}$ & VOLUME 1 & NOMOR 1 & HALAMAN 1-70 & $\begin{array}{c}\text { ISSN 2655-8823 }(p) \\
\text { ISSN - }(e)\end{array}$ \\
\hline
\end{tabular}

pria, tua, muda cacat atau normal, bekerja atau pengangguran, kaya atau miskin. Konflik yang disertai dengan kekerasan membuat orang menjadi enggan untuk berpartisipasi dalam proses pengambilan keputusan, sementara situasi pasca konflik sering menciptakan kesempatan yang sangat luas untuk pengambilan keputusan. Perdamaian perlu dikembangkan bersama masyarakat , bukan 'untuk' masyarakat,

2. Kepemerintahan Yang Baik Kombinasi antara berbagai lembaga, hukum dan perundangan, prosedur serta norma yang memberikan kesempatan kepada masyarakat untuk mengemukakan pendapat dan memperjuangkan kepentingannya melalui cara-cara yang dapat diprediksi dan adil merupakan landasan pemerintah yang baik. Masyarakat yang tata pemerintahannya baik harus mampu mengelola konflik secara konstruktif supaya sumber penyebab konflik dapat ditangani tanpa melalui kekerasan. Tahap pra atau pasca konflik sangat mendukung untuk mengembangkan perdamaian melalui pembentukan dan pembaruan struktur dan lembaga (pemerintah) utama yang mengarahkan dan mengatur Kehidupan masyarakat. Misal struktur perekonomian, militer dan kekuatan polisi serta sistem keadilan.

\section{HASIL DAN PEMBAHASAN Fakta Konflik}

Berlakunya praktek ekonomi politik ultra liberal yang mengakibatkan investasi terhadap sumber kekayaan alam skala luas, berimplikasi pada konflik agraria di seluruh wilayah tanah-air. Konflik agraria yang

\footnotetext{
2 http://www.kpa.or.id/news/blog/perampasantanah-petani-karawang-solidaritas-makin-meluas/ diakses pada 2 April, 2018.
}

mengemuka menjadi persoalan nasional, ditandai dengan merebaknya letusan konflik perebutan tanah antara petani Karawang dengan korporasi properti PT. APL/PT. SAMP yang dalam pandangan masyarakat dibantu oleh aparat Kepolisian serta preman bayaran pada tahun 2016 lalu. ${ }^{2}$

Berbagai dukungan datang secara bergiliran, di antaranya datang dari Aliansi Petani Plasma, Gerakan Mahasiswa Nasional Indonesia (GMNI), FPPI, hingga Front Aktivis Mahasiswa Unpad (FAM Unpad). Para pejuang petani menuntut pemerintah agar menyelesaikan konflik agraria antara perusahaan dengan warga. Mereka pun meminta pemerintah membebaskan 13 orang yang telah ditangkap oleh satuan Brimob. Dalam konflik ini, diduga terjadi praktik "pengadilan hitam", adanya indikasi keberpihakan pemerintah Kab. Karawang, Pengadilan Negeri Kab. Karawang serta aparat Polres Kab. Karawang terhadap korporasi properti yang menjadi salah satu pemain dalam drama konflik ini.

\section{Penyebab Konflik}

Penyebab konflik yang melibatkan pihak petani dan simpatisan petani Kabupaten Karawang dengan anak perusahaan PT. APL, yaitu PT. SAMP, adalah ketika para petani merasa terampas lahan taninya oleh pihak korporasi properti yang telah disebutkan. Selain itu, tidak adanya ganti rugi dan usaha pemenuhan kebutuhan hidup para petani pasca "perampasan" lahan tani yang mereka miliki. Hingga mencapai tahapan konflik yang semakin memuncak, pihak PT. SAMP belum memberikan klarifikasi maupun perbincangan terbuka terhadap para petani perihal untung-rugi yang akan diberikan. Hingga pada saat pihak korporasi properti tersebut bersikeras hingga meminta perlindungan pihak kepolisian dan preman bayaran dalam menghadang demonstrasi 


\begin{tabular}{|c|c|c|c|c|}
\hline $\begin{array}{c}\text { JURNAL } \\
\text { KOLABORASI RESOLUSI KONFLIK }\end{array}$ & VOLUME 1 & NOMOR 1 & HALAMAN 1-70 & $\begin{array}{c}\text { ISSN 2655-8823 }(p) \\
\text { ISSN - }(e)\end{array}$ \\
\hline
\end{tabular}

para petani dan aliansi-aliansi yang berpartisipasi membantu perjuangan para petani Kab. Karawang.

\section{Pemicu Konflik}

Tidak cukup dengan peradilan hitam. Sepanjang berlangsungnya konflik, PT. SAMP tak henti-hentinya melakukan tindakan kriminalisasi terhadap para petani dengan tuduhan menyerobot tanah. Namun tak satupun terbukti bersalah sebagaimana yang dituduhkan. Korban kriminalisasi terakhir ialah Ratna Ningrum (mantan Kades Margamulya) yang dituduh melakukan pemalsuan salinan surat $\mathrm{C}$ desa. Padahal tuduhan itu sama sekali tidak terbukti. Justru rekayasa hitam kembali dilakukan oleh kejaksaan dalam surat tuntutan. Anehnya lagi pengadilan tetap memvonis Ratna Ningrum bersalah dengan kurungan 6 bulan penjara. ${ }^{3}$

Disamping peradilan hitam dan kriminalisasi yang sering dilakukan oleh PT. SAMP, kekerasan pun menimpa para petani. Hal yang sulit diterima akal sehat adalah, kekerasan dilakukan oleh preman bayaran yang didukung oleh aparat.

Tanah yang telah kuasai, dikelola dan dimanfaatkan oleh para petani secara turun temurun selama berpuluh-puluh tahun adalah dilindungi oleh UUD 1945 pasal 33 yang diturunkan melalui UUPA no 5 tahun 1960. Dalam isinya dijelaskan petani sebagai tenaga produktif meiliki hak yang sangat absolut atas tanah bagi kesejahteraan hidupnya. Adapun penguasaan fisik tanah yang dilengkapi oleh bukti kepemilikan berupa girik/leter $\mathrm{C}$ dan ketaatan membayar Pajak Bumi dan Bangunan kepada Negara. Namun, kini tanah itu harus jatuh ke pangkuan PT. SAMP yang secara penuh diakuisisi oleh Kompeni Agung Podomoro melalui perampasan yang dalam tindakannya menyertakan kejaksaan, Pengadilan dan ribuan aparat kepolisian.

Saat jalannya eksekusi, massa yang menghadang pasukan brimob meminta

\footnotetext{
3 https://www.change.org/p/selamatkan-tanah-danpetani-tiga-desa-di-kabupaten-karawang diakses pada 2 April, 2018.
}

Kapolres Karawang menunjukkan bukti kepemilikan PT. SAMP dan menunjukkan batas-batas tanah. Namun, Kapolres tidak dapat membuktikannya. Justru jawaban atas pertanyaan massa adalah berupa semprotan water cannon dan pentungan kepada massa petani dan massa yang bersolidaritas.

Kebenaran, kemanusiaan dan keadilan yang sesuai dengan falsafah hidup bangsa Indonesia (Pancasila, sila ke-2, dan ke-5) telah diinjak-injak oleh Aparat kepolisian dan Pengadilan sesat di dalam eksekusi.

\section{Aktor Konflik}

Dalam konlfik agraria yang mengakibatkan Petani Kab. Karawang Kec. Teluk Jambe Barat menjadi korban. Alasan ini bukanlah suatu playing victim karena petani kerap dianggap sebagai "orang kecil", lantas pemerintah dikambing hitamkan. Alasan ini diperkuat oleh fakta pemerintah memberikan izin kepada perusahaan dalam pengelolaan secara keseluruhan tanpa memperhitungkan hak masyarakat dalam mengelola lahan ulayat tersebut. Begitu pula dengan nasib masyarakat yang begitu bergantung kepada tahan ulayat tersebut sebagai sumber mata pencaharian sebagai tani hingga sebagai lahan tempat tinggalnya.

Adanya dugaan indikasi kerjasama antara pemerintah Kab. Karawang dengan PN Kab. Karawang maupun Polres Karawang yang disinyalir tidak pro rakyat. Sehingga membuat terjadinya pemicu konflik berkepanjangan. Ditambah lagi atas diturunkannya suatu legalitas kepengelolaan lahan kepada PT. SAMP oleh pemerintah Kab. Karawang yang tidak diikuti dengan resolusi win-win solution antara PT.SAMP dengan masyarakat setempat (petani padi Kab. Karawang Kec. Teluk Jambe Barat). Dalam kasus ini, Pemerintah Kab. Karawang gagal menjadi advokator maupun fasilitator atas 


\begin{tabular}{|c|c|c|c|c|}
\hline $\begin{array}{c}\text { JURNAL } \\
\text { KOLABORASI RESOLUSI KONFLIK }\end{array}$ & VOLUME 1 & NOMOR 1 & HALAMAN 1-70 & $\begin{array}{c}\text { ISSN 2655-8823 }(p) \\
\text { ISSN - }(e)\end{array}$ \\
\hline
\end{tabular}

pemenuhan hak eks petani padi Kab. Karawang Kec. Teluk Jambe Barat.

\section{Dampak}

Lalu, bagaimana nasib para petani yang terusir dari lahan dan kampung halamannya sendiri? Hingga saat ini (2018) mereka masih memiliki gubug tempat tinggal dan lahan yang dapat dikelola. Mereka masih hidup di bawah garis kemiskinan. Hingga mencapai tidak memiliki rumah (tuna wisma) dan tidak memiliki tanah (tuna kisma). Tentu saja fakta ini hanya akan menambah panjangnya sederetan nama korban keangkaramurkaan republik.

Dampak selanjutnya pun membuat kredibilitas Pengadilan Negeri (disingkat PN) Kabupaten Karawang dipertanyakan perihal kenetralannya dalam penegakan keadilan. Mengingat dalam kasus ini, PN Kabupaten Karawang cenderung menunjukkan keberpihakannya terhadap pihak korporasi properti yang faktanya telah merampas lahan pertanian petani Kabupaten Karawang.

\section{PEMBAHASAN}

\section{Analisis Resolusi Konflik Dengan Pendekatan Teori Konflik}

Pada dasarnya, konflik agraria yang terjadi antara pihak korporasi properti (PT. SAMP, dalam naungan PT. APL) dengan petani Kabupaten Karawang merupakan permasalahan atas kepentingan ekonomi. Dalam kasus ini, petani Kabupaten Karawang dinilai sebagai pihak yang dirugikan atas perampasan lahan yang begitu saja mampu diakuisisi oleh pihak korporasi properti yang telah disebutkan sebelumnya. Atas perampasan lahan tani ini, akibatnya petani Kabupaten Karawang mengalami mata pencahariannya hilang hingga tempat tinggalnya sirna begitu saja. Tentu, konflik yang terjadi dalam kasus ini begitu menitikberatkan pihak petani yang sangat dirugikan, hingga menggaet simpati dari beberapa organisasi pelajar sampai kepada berbagai serikat tani di Indonesia.

Berkaitan dengan teori yang diungkapkan oleh Fisher, konflik yang terjadi antara PT. SAMP dengan petani Kabupaten Karawang Kec. Teluk Jambe Barat ini termasuk ke dalam konflik manifest; yaitu konflik yang memerlukan berbagai tindakan untuk mengatasi penyebab, pemicu dan pelaksanaan intervensi atas efek yang ditimbulkan. Konflik yang memiliki alur ini seakan-akan menjadi konflik berkepanjangan yang belum dapat ditemukan titik temu atas intervensi guna melahirkan kata damai.

Dalam kasus ini, ada pun pendekatan dengan teori konflik kebutuhan manusia. Penanganan dengan menggunakan dasar teori kebutuhan manusia dianggap tepat karena konflik yang terjadi antara PT. SAMP dengan Petani Kab. Karawang Kec. Teluk Jambe Barat ini didasari dari perebutan kebutuhan dasar manusia; tentunya menyangkut fisik, mental, dan sosial. Terutama bagi para petani yang merasa terdzolimi atas langkah pemerintah Kab. Karawang yang dianggap tidak bijaksana dalam menyokong kesejahteraan para petani dan sekaligus menjadi penyebab dalam konflik ini.

Menurut Marx (1867), fungsi Negara tidak lebih dari penjagaan kepentingankepentingan kelas ekonomis yang berkuasa dengan jala kekerasan. Pemerintah adalah sebuah manifestasi dan pertahanan dari kekuasaan ekonomi. Moralitas dan agama sebuah masyarakat adalah sarana bagi kelas yang berkuasa untuk mempertahankan kedudukannya dengan mempunyai ideologinya sendiri yang diterima sebagai kepentingan semua kelas. Sebuah fenomena yang dilukiskan Marx sebagai "kesadaran palsu" karena semua kelas secara keliru yakin akan objektivitas dan universal peraturan-peraturan dan cita-cita yang sebenarnya hanyalah ungkapan kepentingan-kepentingan kelas.

Sebagai intervensi penyelesaian konflik dalam kasus ini, penerapan prinsip win-win solution seyogyanya diterapkan guna menetralisir permasalahan yang tak kunjung menemukan titik terang atas keadilan bagi pihak petani. Dengan menimbang manajemen konflik perlu 


\begin{tabular}{|c|c|c|c|c|}
\hline $\begin{array}{c}\text { JURNAL } \\
\text { KOLABORASI RESOLUSI KONFLIK }\end{array}$ & VOLUME 1 & NOMOR 1 & HALAMAN 1-70 & $\begin{array}{c}\text { ISSN 2655-8823 }(p) \\
\text { ISSN - }(e)\end{array}$ \\
\hline
\end{tabular}

diperhatikan dalam menanggapi konflik ini, sehingga konflik yang terjadi antara kedua belah pihak mampu diselesaikan bahkan memberikan dampak positif untuk keduanya.

Diperlukannya mediasi yang benarbenar dimediatorkan pihak yang netral (dalam kasus ini, PN hingga kepolisian resor Karawang pun tidak menunjukkan kenetralannya). Sebagai pekerja sosial yang aktif dalam resolusi konflik atau yang bergerak dalam NGO penanganan konflik, diharapkan mampu menjadi pihak penengah atas konflik yang berlangsung. Kemudian, pekerja sosial pun dapat membantu pihak petani dalam mengadvokasikan hak-hak petani (terutama hak untuk hidup dengan kelayakan) dalam mencapai keberfungsian sosial para petani. Hal tersebut dilakukan atas dasar pemerintah Kab. Karawang yang salah mengambil tindakan yang tidak menggunakan partisipasi masyarakat dalam mengambil keputusan. Dengan menjadi pihak enabler atas kebutuhan petani dan pihak korporasi properti yang bersangkutan, nampaknya pekerja sosial dapat berkolaborasi dalam penerapan prinsip win-win solution . Pekerja sosial mampu saja bernegosiasi dengan pihak korporasi properti untuk memberikan lahan pekerjaan terhadap para petani yang terampas lahannya (berkolaborasi dalam proyek bisnis yang dilakukan korporasi tersebut). Sehingga, walaupun lahannya "terampas", para petani tidak begitu saja kehilangan sumber penghasilan dan tempat tinggal.

\section{Merealisasikan Perdamaian dengan Partisipasi Masyarakat}

Meningkatkan partisipasi masyarakat dalam pengambila keputusan merupakan salah cara yang adil dalam kehidupan struktural masyarakat. Analoginya adalah, ketika eksekutif dan legislative terpilih oleh masyarakat sipil, maka di situlah diharuskannya suatu bangsa memiliki sinergitas yang tinggi dalam membentuk strtuktur yang harmonis. Partisipasi termasuk ke dalam HAM, yang merupakan prinsip yang diterima secara luas dalam pembangunan keputusan-keputusan yang akan mempengaruhi hidup khalayak. Artinya, segala hal yang dilakukan tidak lain diperuntukkan untuk khalayak. Karena dalam mengambil setiap keputusan akan berdampak kepada hidup masyarakat (Fisher, 2000).

Perdamaian dan partisipasi masarakat merupakan pembentukan hubungan yang baik dan menimbulkan rasa saling memiliki antar sesama; walaupun dengan kondisi sosial yang plural. Dalam suatu masyarakat yang memiliki perdamaian positif, Fisher berasumsi bahwa anggota masyarakat cukup diberdayakan sehingga mereka berpartisipasi seara aktif dalam pengambilan keputusan. Sebaliknya, jika yang terjadi adalah perdamaian negative dan penindasan, maka orang akan cenderung pasif dan tidak terlalu berminat untuk terlibat dalam masalah politik dan sosial (apatis).

Fenomena konkret yang mampu menggambarkan atas asumsi yang disampaikan oleh Fisher terjadi pada kasus konflik agraria di Kab. Karawang Kec. Teluk Jambe Barat ini. Seakan-akan terbungkam, aspirasi masyarakat (re: petani) tidak dapat tersampaikan ke dalam nurani penguasa. Alih-alih mempertahankan haknya, justru kekerasan yang didapatkan oleh petani sekitar maupun simpatisan Petani Kab. Karawang. Hal tersebut tentunya melahirkan tanda Tanya besar atas tingkah yang dilakukan oleh pemerintah Kab. Karawang yang dinilai tak mampu menjadi pelindung atas pemenuhan hak warganya.

Bagaikan dua mata pisau, konflik dapat bersifat membangun atau merusak bergantung pada cara penanganan dan pengelolaannya. Jika terdapat mekanisme yang efektif dan diterima secara luas untuk mengemukakan pendapat dan bertukar pikiran atau aspirasi, perubahan dapat berlangsung secara damai dan setiap pendapat ikut dipertimbangakn. Namun sebaliknya, fakta fenomena konflik agraria 


\begin{tabular}{|c|c|c|c|c|}
\hline $\begin{array}{c}\text { JURNAL } \\
\text { KOLABORASI RESOLUSI KONFLIK }\end{array}$ & VOLUME 1 & NOMOR 1 & HALAMAN 1-70 & $\begin{array}{r}\text { ISSN 2655-8823 }(p) \\
\text { ISSN - }(e)\end{array}$ \\
\hline
\end{tabular}

di Kab. Karawang ini dapat menjadi contoh atas belum berhasilnya konflik dapat membangun. Dalam kasus ini, sarana untuk mengemukakan pendapat dihalangi dan msrayakat melihat bahwa adanya suatu penindasan, maka kemungkinan timbulnya frustasi dan kekerasan akan lebih besar (Fisher, 2000).

\section{KESIMPULAN DAN SARAN Kesimpulan}

Konflik merupakan suatu peristiwa atau fenomena sosial yang dapat dikatakan tidak mampu terlepas dalam dinamika kehidupan manusia. Menurut Karl Marx (1867), hakekat kenyataan sosial adalah konflik dan kenyataan sosial itu sendiri dapat ditemukan di mana-mana. Bagi Marx konflik sosial adalah pertentangan antara segmen-segmen masyarakat untuk memperebutkan aset-aset yang bernilai. Biasanya konflik terjadi karena perebutan sumber daya, baik sumber daya politik, sosial, ekonimi, atau simbolik.

Munculnya konflik agraria dalam kehidupan masyarkat Indonesia perlu menjadi sorotan penting dalam penanganan dan mengusahakan langkah preventif untuk mencegah kasus seperti bahasan di atikel ini terjadi kembali. Konflik agraria yang terjadi di Kab. Karawang Kec. Teluk Jambe Barat dapat menjadi cerminan bahwa hal yang berkaitan dengan kebutuhan manusia tidak dapat dianggap sepele. Segala sesuau yang berkaitan dengan kebutuhan manusia perlu mendapatkan perhatian yang lebih dalam menjaga dan merealisasikan stabilitas dinamika yang positif dalam kehidupan manusia. Kebutuhan manusia menjadi aspek vital dalam keberlangsungan hidup; karena hal ini sangat erat hubungannya dengan mental dan status sosial. karena pada dasarnya, aspek kebutuhan manusia berperan secara kompleks pada struktur sosial, stabilitas, dan hubungan antar element yang saling berkesinambungan.

\section{Saran}

Kegiatan majanemen konflik dengan resolusi konflik atas prinsip win-win solution dapat menjadi jalan penyelesaian konflik agraria yang terjadi pada petani Kabupaten Karawang. Hal tersebut tentunya bukan semata-mata untuk menghapuskan dasar terjadinya konflik atas semena-menanya upaya pemenuhan kepentingan sepihak ; melainkan konflik diharapkan mampu menjadi dasar terjadinya hal positif yang sebelumnya dirasa merugikan.

Pemaksimalan fungsi partisipasi masyarakat dengan struktur kepemerintahan seyogyanya mampu berkolaborasi dalam suatu pembangunan sekaligus menghasilkan sikap masyarakat madani. Selanjutnya, peran pekerja sosial sebagai agent of harmony yang tergabung dalam NGO pada ranah resolusi konflik harus lebih dioptimalkan. Hal tersebut dikarenakan terjadinya konflik ini bukan hanya tentang kepentingan atau kebutuhan suatu pihak saja; melainkan bersangkutan dengan hal kemanusiaan dan kesejahteraan masing-masing pihak; termasuk point outcome yang mampu memberikan dampak negatif atau positif yang bergantung pada manajemen konflik dan pengelolaan konflik yang dilakukan.

Lalu, mengapa harus pekerja sosial yang tergabung dalam NGO resolusi konflik? Dalam kasus ini, masyarakat (re: petani Kab. Karawang beserta aliansi tani) seakan-akan telah memakai kaca mata kuda kepada pihak kepolisian yang dianggap tidak netral. Sehingga, pekerja sosial yang dimaksud hiradapkan mampu menjadi mediator yang netral guna pemenuhan kebutuhan manusia dari masing-masing element yang berkonflik. Dengan demikian, win-win solution yang diinginkan dapat terealisasi.

\section{DASTAR PUSTAKA}

\section{Buku :}

Fisher, Simon, dkk.2000. Manajemen Konflik Keterampilan dan Strategi 


\begin{tabular}{|c|c|c|c|c|}
\hline $\begin{array}{c}\text { JURNAL } \\
\text { KOLABORASI RESOLUSI KONFLIK }\end{array}$ & VOLUME 1 & NOMOR 1 & HALAMAN 1-70 & $\begin{array}{c}\text { ISSN 2655-8823 }(p) \\
\text { ISSN - }(e)\end{array}$ \\
\hline
\end{tabular}

untuk Bertindak. Jakarta: British Council.

Raho, Bernard. 2007. Teori Sosiologi

Modern. Jakarta : Prestasi Pustaka

Publisher.

Hokenstad M.C. dan James Midgley (1997), "Realities of Global Interdependence:Challenges for Social Workers in a New Century" dalam Hokenstad dan Midgley, Issues in International Social Work: Global Challenges for a New Century, Washington D.C.: NASW Press.

Hokenstad M.C., Khinduka S.K., dan James Midgley (1992), Profiles in International Social Work, Washington D.C: NASW Press.

Website :

https://nasional.tempo.co/read/588104/sen gketa-lahan-karawangdimenangkan-agungpodomoro/full\&view $=$ ok $\quad$ diakses pada 2 April, 2018.

http://www.kpa.or.id/news/blog/perampasa n-tanah-petani-karawangsolidaritas-makinmeluas/ diakses pada 2 April, 2018.

https://www.change.org/p/selamatkantanah-dan-petani-tiga-desa-dikabupaten-karawang diakses pada 2 April, 2018.

http://www.zonasiswa.com/2014/11/sengk eta-internasional-penyebab.html diakses pada 2 April, 2018.

http://digili.uinsby.ac.id/2560/5/Bab\%202. pdf diakses pada 2 April, 2018.

www.policy.hu/suharto/modul a/makindo 33.htm diakses pada 2 April, 2018.

http://www.gresnews.com/berita/hukum/8 7400-kpa-konflik-agrariakarawang-perampasan-tanah/ diakses pada 4 Desember, 2018.

http://www.gresnews.com/berita/hukum/8 6846-konflik-petani-karawanglawan-pt sampmeruncing-telah-24tahun-tak-terselesaikan// diakses pada 4 Desember, 2018. https://nasional.tempo.co/read/589235/peta ni-karawang-desak-polisiusutperampasanlahan/full\&view $=0$ $\underline{\mathrm{k}}$ diakses pada 4 Desember, 2018.

https://megapolitan.antaranews.com/berita/ 38703/petani-karawang-tuntutpengembalian-lahan-ke-perusahaan diakses pada 24 januari 2019. 